\title{
Craniosynostosis associated with FGFR3 pro250arg mutation results in a range of clinical presentations including unisutural sporadic craniosynostosis
}

Mothercare Unit of Clinical Genetics and Fetal Medicine, Institute of Child Health, 30 Guilford Street, London WC1N 1EH, UK

W Reardon

M Baraitser

R M Winter

Molecular Genetics Unit, Institute of Child Health, London WC1N 1EH, UK

D Wilkes

P Rutland

L J Pulleyn

$S$ Malcolm

Department of Medical Genetics, Medical School, Foresterhill, Aberdeen AB9 2ZD, UK

J C S Dean

Craniofacial Unit, Great Ormond Street Hospital for Children, London WC1N 3JH,

UK

R D Evans

B M Jones

R Hayward

Department of Radiology, Great Ormond Street

Hospital for Children, London WC1N 3JH, UK

C M Hall

Department of Medical Genetics, Belfast City Hospital, Belfast BT9 $7 \mathrm{AB}$, UK N C Nevin

Correspondence to: Dr Reardon.

Received 4 February 1997 Accepted for publication 25 March 1997

William Reardon, David Wilkes, Paul Rutland, Louise J Pulleyn, Sue Malcolm, John C S Dean, Robert D Evans, Barry M Jones, Richard Hayward, Christine M Hall, Norman C Nevin, Michael Baraitser, Robin M Winter

\begin{abstract}
Several mutations involving the fibroblast growth factor receptor (FGFR) gene family have been identified in association with phenotypically distinct forms of craniosynostosis. One such point mutation, resulting in the substitution of proline by arginine in a critical region of the linker region between the first and second immunoglobulin-like domains, is associated with highly specific phenotypic consequences in that mutation at this point in FGFR1 results in Pfeiffer syndrome and analogous mutation in FGFR2 results in Apert syndrome. We now show that a much more variable clinical presentation accompanies analogous mutation in the FGFR3 gene. Specifically, mental retardation, apparently unrelated to the management of the craniosynostosis, appears to be a variable clinical consequence of this FGFR3 mutation.

(F Med Genet 1997;34:632-636)
\end{abstract}

Keywords: craniosynostosis; FGFR3; pro250arg mutation

The craniosynostoses represent a diverse group of disorders, which, by definition, involve premature fusion of the cranial sutures. Many of these conditions are genetically determined and family studies have been an important element in the emergence of clinically distinct syndromes of craniosynostosis. ${ }^{12}$ For the most part these syndromes are well defined, although the precise classification of individual cases/families may be the subject of good natured dispute between friends. ${ }^{3-8}$ Apart from well established clinical differences setting it apart from several other syndromes of craniosynostosis, ${ }^{9}$ Saethre-Chotzen syndrome also seems to be molecularly distinct in that the linkage and cytogenetic data mapping the locus for this disorder to chromosome $7 p$ exclude a causative association with mutations of the fibroblast growth factor receptors or their ligands. ${ }^{10-15}$ Indeed this has been confirmed with the recent identification of mutations in the TWIST gene in patients with SaethreChotzen syndrome. ${ }^{1617}$

Following the description of fibroblast growth factor receptor 2 (FGFR2) mutations in Crouzon syndrome, ${ }^{18}$ mutations in the FGFR1, 2, and 3 loci have now been extended to Pfeiffer syndrome, ${ }^{519}$ Apert syndrome, ${ }^{20}$ Crouzon syndrome with acanthosis nigricans, ${ }^{21} 22$ Jackson-Weiss syndrome, ${ }^{23}$ and Beare-Stevenson syndrome. ${ }^{24}$ Craniosynostosis is common to all these conditions, the basis of clinical differentiation focusing on the associated features. Additionally, mutations of FGFR3 have been described in association with skeletal dysplasias, specifically achondroplasia, hypochondroplasia, and thanatophoric dysplasia both with and without cloverleaf skull malformation. ${ }^{25}$

While in Pfeiffer syndrome the association of craniosynostosis with broad thumbs and halluces has been described in association with a range of mutations at the FGFR2 locus, ${ }^{526}$ the first mutation described was in the FGFR1 locus on chromosome $8 .{ }^{19}$ The same missense mutation was identified in five families with Pfeiffer syndrome, resulting in the substitution of proline 252 by arginine in the linker region between the second and third immunoglobulin-like domains of the extracellular component of the receptor. An analogous mutation in the FGFR2 gene, proline 253 substitution by arginine, was described as one of two mutations underlying Apert syndrome, in which the craniosynostosis is associated with syndactyly of the hands and feet. ${ }^{20}$ More recently, Bellus et $a l^{27}$ have described substitution of proline 250 by arginine in the FGFR3 gene in association with autosomal dominant craniosynostosis of non-specific phenotype.

Arising from the observation that two families thought clinically to represent Pfeiffer syndrome, but in whom linkage data were consistent with a $4 \mathrm{p} 16.3$ localisation, in contrast to the expected 8 centromere (FGFR1) or 10q25 (FGFR2), Bellus et $a l^{27}$ sought mutations at the FGFR3 locus on $4 p$ as the likely basis of the phenotype. The mutation identified, pro250arg, was then sought in a panel of 65 unrelated patients with craniosynostosis with and without limb involvement. A further eigh positive cases were identified, reported as five cases of non-syndromic craniosynostosis and three with features consistent with Crouzon syndrome, Pfeiffer syndrome, and SaethreChotzen syndrome. The authors suggested that the phenotypic spectrum of this mutation 
was broad, encompassing unilateral and bilateral coronal craniosynostosis, often associated with no clinical evidence of digital abnormalities but that radiological examination of the digits might show short, broad middle phalanges of the fingers and absent or hypoplastic middle phalanges of the toes. ${ }^{27}$

An important consideration is that these observations derive from families with craniosynostosis segregating. The full range of phenotypic presentations of craniosynostosis in which it would be appropriate to look for this mutation is still unclear. Moreover, much of craniosynostosis is seen in apparently sporadic situations with clinically normal parents and the question of recurrence risk in future pregnancies is the major concern. It is uncertain as yet what contribution, if any, the identification of the pro250arg mutation in FGFR3 may make to this practical problem. Finally, since most patients with craniosynostosis do not have an identifiable syndromic form and the craniosynostosis often involves only a single suture, it would be valuable to know what proportion of unisutural cases might be the result of this mutation which appears to be associated with a variable phenotype. This communication addresses these issues in light of the results we have obtained from screening 165 patients with craniosynostosis for the FGFR3 pro250arg mutation.

\section{Materials and methods}

PATIENTS

Samples were analysed from 165 patients with craniosynostosis. Of these, 45 represented familial craniosynostosis with or without limb malformations for whom no mutation had been identified at the FGFR1 and FGFR2 loci, and 120 were clinically thought to represent sporadic cases. From available details of skull radiology, 47 patients with unisutural craniosynostosis were known in the series. This latter group included both familial and sporadically occurring patients.

\section{LABORATORY ANALYSIS}

DNA was extracted from lymphocytes by salting out. ${ }^{28}$ Primers amplifying the intron between exons 6 and 7 of FGFR3 from genomic DNA were used. The primer sequences are 5'-CGGCAACTACACCTGCGTCGTG-3' forward from exon 6 of FGFR3 and 5'-CTTGAGCACGGTAACGTAGGG-3' reverse from the end of exon 7 of FGFR3. PCR conditions were $200 \mathrm{ng}$ of genomic DNA, $10 \mathrm{mmol}^{-1}$ Tris, $\mathrm{pH} 8.3,1.5$ $\mathrm{mmol} \mathrm{l}^{-1} \mathrm{MgCl}, 16 \mathrm{~mol} \mathrm{l}^{-1}\left(\mathrm{NH}_{4}\right)_{2} \mathrm{SO}_{4}, 200 \mu \mathrm{mol}$ $\mathrm{l}^{-1}, \mathrm{dNTP}, 50 \mathrm{pmol}$ of each primer, and $0.5 \mathrm{U}$ Taq polymerase and DMSO was added to a final concentration of $10 \%$ in a total volume of $50 \mu \mathrm{l}$ : 30 cycles of (1) $94^{\circ} \mathrm{C} \times 30$ seconds, (2) $58^{\circ} \mathrm{C} \times 30$ seconds, (3) $72^{\circ} \mathrm{C} \times 40$ seconds. The wild type, $351 \mathrm{bp}$ product, which includes most of exon 7 of FGFR3, is cleaved by the enzyme $N c i$ giving fragments of $319 \mathrm{bp}$ and $32 \mathrm{bp}$. In the presence of the $\mathrm{C} 749 \mathrm{G}$ mutation which underlies the proline substitution, the $319 \mathrm{bp}$ fragment is further cleaved by this enzyme into fragments of 151 and 168 bp (fig 1).

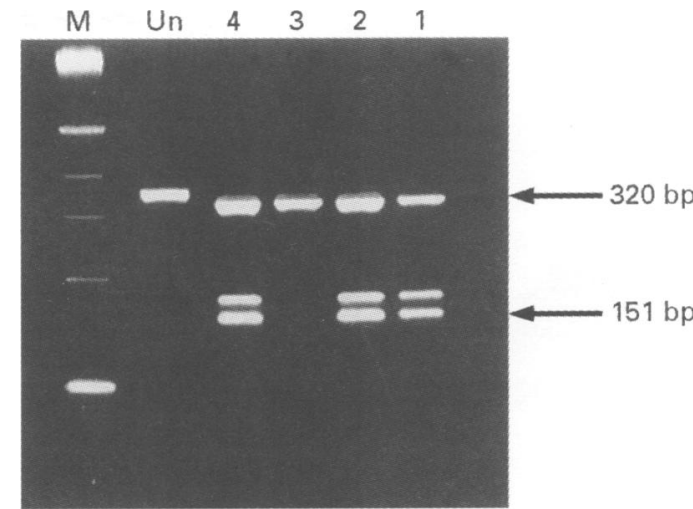

Figure 1 The undigested PCR product (Un) is $351 \mathrm{bp}$ NciI restriction of the normal allele cleaves a $32 \mathrm{bp}$ fragment, producing a 319 bp product. The C749G mutation in FGFR3 creates a NciI site resulting in further digestion products of $168 \mathrm{bp}$ and $151 \mathrm{bp}$. DNA size marker (M) is 100 bp ladder. Family 1 is shown, with affected father and children in lanes 1, 2, and 4 clearly being heterozygous for the mutation and the unaffected mother in lane 3 being homozygous wild type.

\section{Results}

Nine of $165(5.5 \%)$ samples tested proved positive for the mutation. These were found to represent four familial $(4 / 45=8.8 \%)$ and five sporadic cases $(5 / 120=4.2 \%)$ in our series. Two cases presenting with unisutural craniosynostosis without limb malformation were found to have the mutation $(3 / 47=6.4 \%)$.

CLINICAL FEATURES OF THE FGFR3 PRO250ARG MUTATION

Four families were identified with this mutation. Family 1 represents a two generational pedigree which presented with bicoronal craniosynostosis and broad thumbs and halluces in both affected offspring (fig 2). Despite surgical treatment for the craniosynostosis, both patients were assessed as having a mild to moderate degree of mental handicap, requiring special schooling. A likely diagnosis of Pfeiffer syndrome was suggested and examination of the parents showed that the father of the children himself had broad first and second toes with a normal skull both on clinical and radiological examination (fig 2). None of the three subjects carrying the mutation in this family showed cone shaped epiphyses on $x$ ray.

Family 2 is a two generational pedigree, initially considered to represent Saethre-Chotzen syndrome, on the basis of the facial asymmetry, flat forehead, and prominent crus helicis in the affected patient as well as her affected son. The clinically affected mother had unicoronal synostosis radiologically and $x$ ray in her son showed bilateral coronal suture craniosynostosis. This boy has developmental delay and attends special school. Grandparental examination was unremarkable except for brachydactyly in the grandfather. As the mutation was shown to arise de novo in his daughter, this finding is unrelated to the phenotype.

Similarly, family 3 , represented by an affected mother and son, were considered to have Saethre-Chotzen syndrome, in view of the facial asymmetry and prominence of the ear crura in both affected subjects and the facial profile of the boy (fig 3). The craniosynostosis in this family involved the coronal sutures 


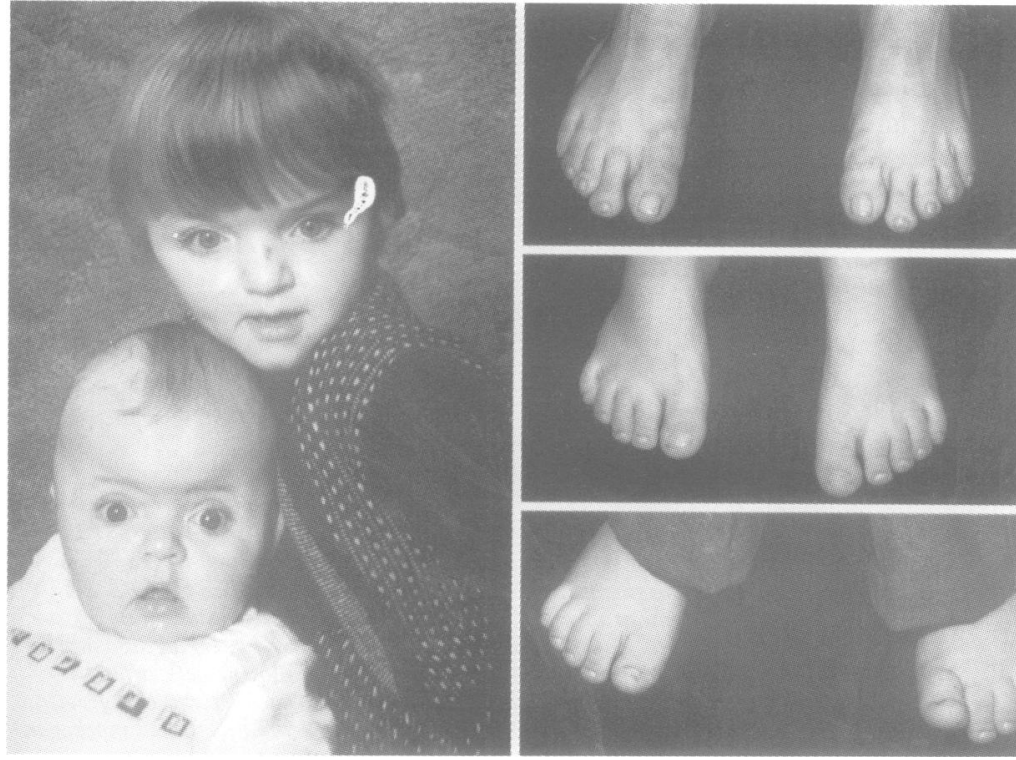

Figure 2 Family 1 showing the craniosynostosis in both children associated with slightly wide halluces in the affected father (top) and children. Note also the somewhat broad second toes in the father.

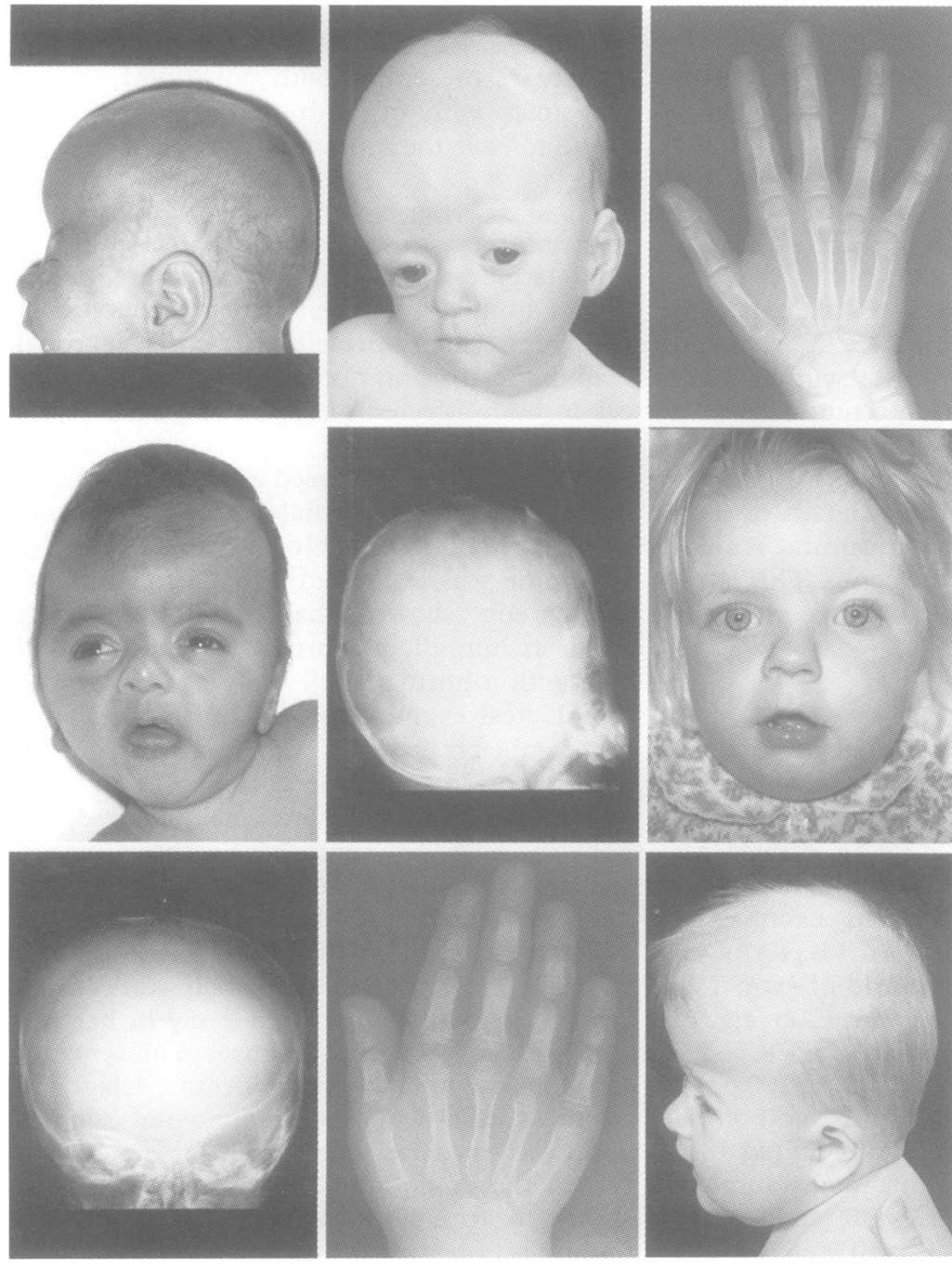

Figure 3 Several clinical features in the patients reported are documented. Top left, case 2, family 3 to show the overlap with Saethre-Chotzen syndrome. Top middle and right, case 5, who has unicoronal synostosis and cone shaped epiphyses of the hand. Second line left and middle frames show case 7 who has multiple suture involvement confirmed on the $x$ ray as well as profound developmental delay. Second line on the right is case 8 who had unisutural craniosynostosis involving the left coronal suture, as shown in her $x$ ray at the bottom left. Case 8 also has cone shaped epiphyses, seen bottom middle. Case 9 is shown in the right hand frame, bottom line, with features which were thought clinically to be consistent with Saethre-Chotzen syndrome. bilaterally. Family 4, comprising an affected mother and daughter, were thought to represent Saethre-Chotzen syndrome in view of the high, flat forehead, the prominent ear crura, and the absence of proptosis and limb malformations. Radiological examination again showed bilateral coronal suture involvement.

Patients 5 to 9 were all sporadic cases, two of whom presented clinically with plagiocephaly in the newborn period and were shown radiologically to have unicoronal synostosis. Although two of these five cases had cone shaped epiphyses radiologically (fig 3), only one patient showed unequivocal clinical evidence of digital abnormality, a broad thumb in case 6 (table 1), who has already been reported elsewhere as he also had DiGeorge syndrome with confirmed $22 \mathrm{q}$ deletion. ${ }^{29}$ It is worth noting the severe developmental delay in case 7 , whose mutation had arisen de novo (fig 4) and whose craniosynostosis involved all sutures except the lambdoid (fig 3). There was no evidence of raised intracranial pressure in this patient and, despite extensive investigation, no other basis for the developmental delay was found.

\section{Discussion}

The clinical profile of the patients in whom we have identified the FGFR3 pro250arg mutation shows wide variability in presentation. In this respect the FGFR3 mutation differs from the clinical observations in patients with substitution of the analogous proline in FGFR1 and FGFR2. The proline 252 to arginine substitution in FGFR1 consistently results in a Pfeiffer syndrome phenotype, whereas the proline 253 to arginine substitution in FGFR2 is one of only two adjacent amino acid substitutions underlying Apert syndrome. The specificity of the Apert syndrome association with the proline 253 to arginine substitution in FGFR2 has been further underlined by the recent report of Oldridge $e t a l^{30}$ in which a rare amino acid substitution known to cause Apert syndrome (serine 252 to phenylalanine) is modified if the adjacent amino acid (proline 253 in wild type) is also altered to serine. These authors showed a range of phenotypes associated with different combinations of amino acid substitutions at the serine 252 proline 253 sequence in wild type FGFR2. In view of these findings, the specificity of the the proline 253 arginine substitution with the Apert syndrome phenotype is all the more remarkable, leading the authors to suggest that the conformation of the mutant FGFR2 giving rise to syndactyly is a function not just of the particular amino acid but also of specific amino acids at neighbouring sites. All four human FGFRs show identical amino acid sequence in this region, ${ }^{31}$ the only mutation in the patients we describe being the proline to arginine substitution. Given the absence of adjacent amino acid changes as phenotype modifiers, as seen in the cases of Oldridge $e t$ $a l,{ }^{30}$ the phenotypic spectrum in the cases we report is surprising.

The group of patients we describe highlight a number of important practical points with 
Table 1 Clinical details of families and patients identified in this report

\begin{tabular}{|c|c|c|c|c|c|c|c|}
\hline & Suture & $\begin{array}{l}\text { Broad } \\
\text { thumbs }\end{array}$ & Hallux & $\begin{array}{l}\text { Cone shaped } \\
\text { epiphyses }\end{array}$ & $\begin{array}{l}\text { Mental } \\
\text { retardation }\end{array}$ & Other features & $\begin{array}{l}\text { Presumptive clinical } \\
\text { diagnosis }\end{array}$ \\
\hline \multicolumn{8}{|l|}{ Family 1} \\
\hline Case 1 & None & No & Broad & No & No & Broad 2nd toes & ?Pfeiffer syndrome \\
\hline Case 2 & Bicoronal & No & Broad & No & Yes & No & \\
\hline Case 3 & Bicoronal & No & Broad & No & Yes & No & \\
\hline \multicolumn{8}{|l|}{ Family 2} \\
\hline Case 1 & Left coronal & No & No & $?$ & No & No & $\begin{array}{l}\text { Saethre-Chotzen } \\
\text { syndrome }\end{array}$ \\
\hline Case 2 & Bicoronal & No & No & $?$ & Yes & Cleft palate & \\
\hline \multicolumn{8}{|l|}{ Family 3} \\
\hline Case 2 & Bicoronal & No & Broad & $?$ & No & No & $\begin{array}{l}\text { Saethre-Chotzen } \\
\text { syndrome }\end{array}$ \\
\hline \multicolumn{8}{|l|}{ Family 4} \\
\hline Case 2 & Bicoronal & No & No & $?$ & No & Flat forehead & $\begin{array}{l}\text { Saethre-Chotzen } \\
\text { syndrome }\end{array}$ \\
\hline \multicolumn{8}{|l|}{ Sporadic } \\
\hline Case 5 & Left coronal & No & Broad & Yes & No & No & Non-specific \\
\hline Case 6 & Multiple & Yes & No & No & $?$ & $\operatorname{Del}(22 q 11)$ & Non-specific \\
\hline Case 7 & Multiple & No & No & No & Yes & $\begin{array}{l}2 / 3 \text { toe } \\
\text { syndactyly }\end{array}$ & ?deletion $7 \mathrm{p} 21$ \\
\hline Case 8 & Left coronal & No & No & Yes & No & No & Non-specific \\
\hline Case 9 & Bicoronal & No & No & No & No & No & $\begin{array}{l}\text { Saethre-Chotzen } \\
\text { syndrome }\end{array}$ \\
\hline
\end{tabular}

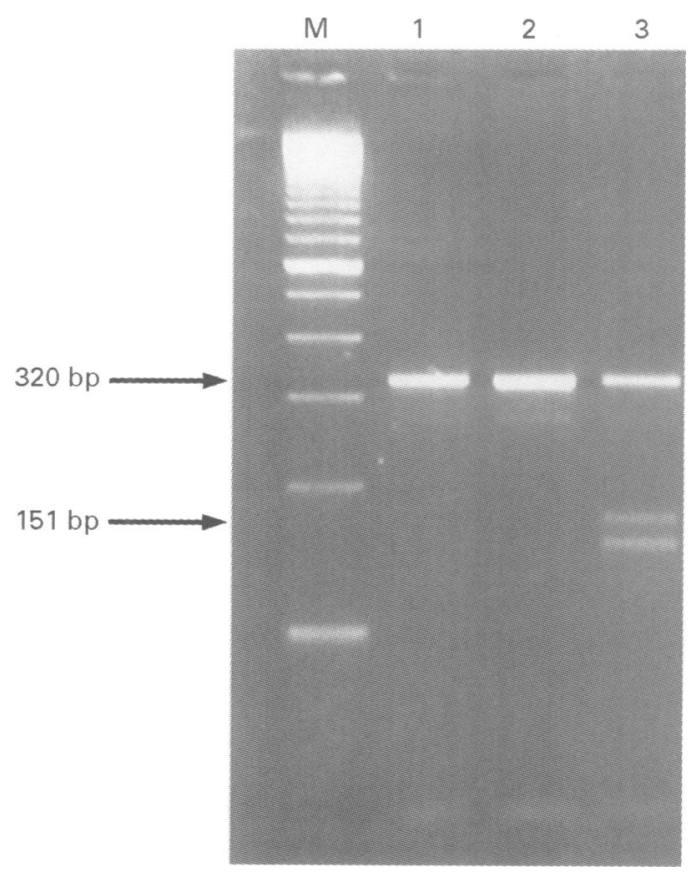

Figure 4 The de novo nature of the mutation in case 8. The affected patient is shown to be heterozygous for the mutation in lane 3, his unaffected parents in lanes 1 and 2.

respect to diagnosis and counselling in patients with craniosynostosis. Firstly, there is significant overlap between the Saethre-Chotzen syndrome phenotype and that of FGFR3 proline 250 arginine substitution. Secondly, mental retardation not related to the craniosynostosis is part of the clinical spectrum in both familial and sporadic cases. Thirdly, the presence or absence of limb abnormalities are not a guide to identification of patients with this underlying mutation. Fourthly, five of our nine cases represent new mutations, suggesting that the $C$ to $G$ transversion which underlies the proline 250 arginine substitution may be a relatively common mutation. Fifthly, the identification of this mutation in association with unisutural craniosynostosis in three cases emphasises the caution with which recurrence risks should be approached in craniosynostosis. Finally, the presence of cone shaped epiphyses in two of the eight cases for whom hand radio- logy was available may assist clinicians in guiding laboratory colleagues as to which mutation to seek in individual cases.

The systematic classification of craniosynostosis syndromes based on associated clinical features has led, in recent years, to the addition of a number of subtypes described in individual families, ${ }^{32}{ }^{33}$ whose clinical features did not fit easily with the known syndromic forms. While one of these has been found to be associated with a point mutation in the MSX2 gene on chromosome $5,{ }^{34}$ another has been mapped to chromosome $4 \mathrm{p}$, in the region of FGFR3. ${ }^{31}$ Perhaps mutations at the FGFR3 locus, encompassing a range of phenotypic presentations such as we describe, may account for several patients with craniosynostosis for whom mutations have not been identified at the other loci known to underlie craniosynostosis.

We are pleased to acknowledge grant support from The Wellcome Trust and the Medical Research Council. We wish to thank the families involved for their assistance.

1 Cohen MM Jr. Craniosynostosis: diagnosis, evaluation and management. New York: Raven Press, 1986.

2 Winter RM, Baraitser M. The London Dysmorphology Data base. Oxford: Oxford University Press, 1997.

3 Baraitser M, Bowen-Bravery M, Saldana-Garcia P. Pitfalls of genetic counselling in Pfeiffer's syndrome. $\mathcal{F}$ Med Gene 1980;17:250-6.

4 Cohen MM Jr. In: Gorlin RJ, Cohen MM Jr, Levin LS. Symdromes of the head and neck. Oxford Monographs on Medical Genetics No 19. Oxford: Oxford University Press, 1990.

5 Rutland P, Pulleyn LJ, Reardon W, et al. Identical mutations in the FGFR2 gene cause both Pfeiffer and Crouzon syndrome phenotypes. Nat Genet 1995;9:173-6.

6 Cohen MM Jr. Craniosynostoses: phenotypic/molecular correlations. Am $\mathcal{f}$ Med Genet 1995;56:334-9.

7 Winter RM, Reardon W. Lumpers, splitters and FGFRs. Am f Med Genet 1996;63:501-2.

8 Cohen MM Jr. A matter of reading English. Am $\mathcal{F}$ Med Gener 1996;63:503-4

9 Reardon W, Winter RM. Saethre-Chotzen syndrome. $\mathcal{F} \mathrm{Med}$ Genet 1994;31:393-6.

10 Brueton LA, van Herwerden L, Chotai KA, Winter RM The mapping of a gene for craniosynostosis: evidence for linkage of the Saethre-Chotzen syndrome to distal chromosome 7p. $\mathcal{F}$ Med Genet 1992;29:681-5.

11 van Herwerden L, Rose CSP, Reardon W, et al. Evidence for locus heterogeneity in acrocephalosyndactyly: a refined localization for the Saethre-Chotzen syndrome locus on distal chromosome $7 \mathrm{p}$ - and exclusion of Jackson-Weiss Hum Genet 1994;54:669-74.

12 Lewanda AF, Cohen MM Jr, Jackson CE, et al. Genetic heterogeneity among craniosynostosis syndromes: mapping the Saethre-Chotzen syndrome locus between D7S 513 and drome loci from 7p. Genomics 1994;19:115-19. 
13 Reardon W, McManus SP, Summers D, Winter RM Cytogenetic evidence that the Saethre-Chotzen gene maps to 7p21.2. Am f Med Genet 1993;47:633-6.

14 Reid CS, McMorrow LE, McDonald-McGinn D, et al. Saethre-Chotzen syndrome with familial translocation chromosome 7p22. Am $\mathcal{f}$ Med Genet 1993;47:637-9.

15 Rose CSP, King AAJ, Summers D, et al. Localization of the genetic locus for Saethre-Chotzen syndrome to a $6 \mathrm{cM}$ region of chromosome 7 using four cases with apparently balanced translocations at 7p21.2. Hum Mol Genet 1994;3: 1405-8.

16 Howard TD, Paznekas WA, Green ED, et al. Mutations in TWIST, a basic helix-loop-helix transcription factor, in TWIST, a basic helix-loop-helix transcription factor,

17 El Ghouzzi V, Le Merrer M, Perrin-Schmitt F, et al. Mutations of the TWIST gene in the Saethre-Chotzen syndrome. Nat Genet 1997;15:42-6.

18 Reardon W, Winter RM, Rutland P, et al. Mutations in the fibroblast growth factor receptor 2 gene cause Crouzon syndrome. Nat Genet 1994;8:98-103.

19 Muenke M, Schell U, Hehr A, et al. A common mutation in the fibroblast growth factor receptor 1 gene in Pfeiffer syndrome. Nat Genet 1994;8:269-74.

20 Wilkie AOM, Slaney SF, Oldridge M, et al. Apert syndrome results from localized mutations of FGFR2 and is allelic with Crouzon syndrome. Nat Genet 1995;9:165-72.

21 Meyers GA, Orlow SJ, Munro IR, et al. Fibroblast growth factor receptor 3 (FGFR3) transmembrane mutation in Crouzon syndrome with acanthosis nigricans. Nat Genet 1995;11:462-4.

22 Wilkes D, Rutland P, Pulleyn LJ, et al. A recurrent mutation, ala391glu, in the transmembrane region of FGFR3 cause Crouzon syndrome and acanthosis nigricans. $f$ Med Genet 1996;33:744-8.

23 Jabs EW, Scott AF, Meyers G, et al. Jackson-Weiss and Crouzon syndromes are allelic with mutations in fibroblas growth factor receptor 2 . Nat Genet 1994;8:275-9.
24 Przylepa KA, Paznekas W, Zhang M, et al. Fibroblast growth factor receptor 2 mutations in Beare-Stevenson cutis gyrata syndrome. Nat Genet 1996;13:492-4.

25 Reardon W. Skeletal dysplasia detectable by DNA analysis. Prenat Diagn 1996;16:1221-36.

26 Reardon W, Winter RM. The molecular pathology of syndromic craniosynostosis. Mol Med Today 1995;1:432-7.

27 Bellus GA, Gaudenz K, Zackai EH, et al. Identical mutations in three different fibroblast growth factor genes in autosomal dominant craniosynostosis syndromes. Nat Genet 1996;14:174-6.

28 Miller SA, Dykes DD, Polesky HF. A simple salting out procedure for extracting DNA from human nucleated cells. Nucleic Acids Res 1988;16:1215.

29 De Silva D, Duffy P, Booth P, et al. Family studies in chromosome 22q11 deletion: further demonstration of phenotypic heterogeneity. Clin Dysmorphol 1995;4:294-303.

30 Oldridge $\mathrm{M}$, Lunt $\mathrm{PW}$, Zackai EH, et al. Genotypephenotype correlation for nucleotide substitutions in the IgII-IgIII linker of FGFR2. Hum Mol Genet 1997;6:137-43.

31 Johnson DE, Williams LT. Structural and functional diversity in the FGF receptor multigene family. Adv Cancer Res 1993;60:1-41.

32 Warman ML, Mulliken JB, Hayward PG, Muller U. Newly recognised autosomal dominant disorder with craniosynostosis. Am ₹ Med Genet 1993;46:444-9.

33 Holloway GE, Phillips HA, Ades LA, et al. Localization of craniosynostosis Adelaide type to 4p16. Hum Mol Genet 1995;4:681-3.

34 Jabs EW, Muller U, Li X, et al. A mutation in the homeodomain of the human MSX2 gene in a family affected with autosomal dominant craniosynostosis. Cell 1993;75:443- 